\title{
Ailesel Akdeniz Ateşi
}

\section{Yüksek Lisans Öğr. Onur ALBAYRAK \\ Prof. Dr. M. Akif ÇÜRÜK}

\section{Ailesel Akdeniz Ateşi Nedir?}

Ailesel Akdeniz Ateşi (FMF) karın, göğüs ve eklem ağrısı ile şişliğinin eşlik ettiği, tekrarlayan ateş nöbetleri ile karakterize genetik bir hastalıktır ${ }^{1}$. Vücutta, karın ve göğüs boşluğu gibi bölgeleri kaplayan 5 tip zarın (Seroza) Ailesel Akdeniz Ateşi ataklarına katılma sıklığı; Karın-Periton, Göğüs-Plevra, EklemSinovya, Kalp-Perikard, Beyin ve merkezi sinir sistemi-Menenks olarak sıralanır. Peritondaki C5a inhibitör aktivite eksikliği öncelikle serozal inflomasyonlar ile yayılarak FMF ataklarına katkıda bulunmaktadır².

Ailesel Akdeniz Ateşi (OMIM: 249100), MEFV(OMIM: 608107) genindeki mutasyonların neden olduğu otozomal resesif bir hastalıktır. Bu gen, kromozom 16p13.3'da haritalanmıştır ve özellikle granülositlerde bulunan pyrin adlı proteini kodlamaktadır ${ }^{3}$.

Ailesel Akdeniz Ateşli hastalar iki fenotipe ayrılırlar. Ateş, karın ağrısı, eklem ağrısı ve göğüs ağrısı gibi tipik atakların görüldüğü hastalar fenotip I, tipik ateş ve karın ağrısı gibi hastalığa özgü ataklar olmadan amiloid nefropatisi gelişen hastalar ise fenotip II olarak sınıflandırıı ${ }^{4}$.

\section{Ailesel Akdeniz Ateşi' nin Tarihçesi}

Ailevi Akdeniz ateşi (FMF) Akdeniz havzasının hastalığı olarak tanımlanır. Illk olarak Musevi ve Ermeni hastalarda gözlenmiş, daha sonra Türkler ve Araplar arasında da saptanmıştır. Mitolojik çağlarda ortadoğuda yaşayan Museviler güneyde Yahudi, kuzeyde İsrail adını almıştır. 1492'de İspanyadan ayrılan Museviler daha sonra Osmanlı İmparatorluğuna katılmışlardır. Bu

*Çukurova Üniversitesi Tıp Fakültesi, T ıbbi Biyokimya Anabilim Dalı, ADANA 
şekilde göçlerle hastalık yayılmıştır ${ }^{4}$ (Şekil1).

Özellikle Akdeniz çevresindeki ülkeleri (Museviler, Ermeniler, Araplar ve Türkler) etkileyen; tekrarlayan ateş ve poliserozit atakları ile karakterize bir hastalıktır ${ }^{3,5}$.

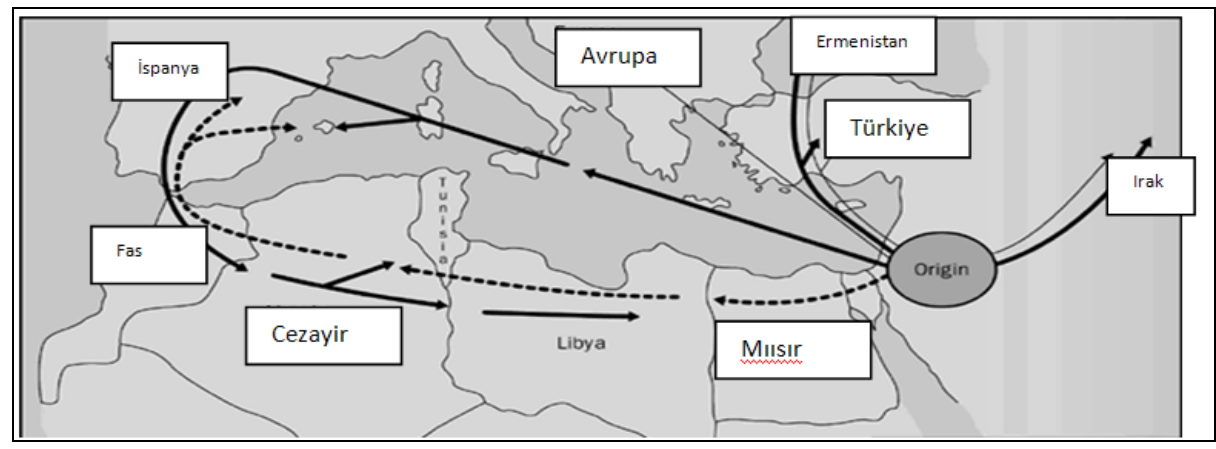

Şekil 1. Ailesel Akdeniz Ateşi hastalığının göç haritası

Akdeniz tanımlamasının aksine ülkemizde, Ailesel Akdeniz Ateşi daha çok İç Anadolu (Sivas, Tokat, Kayseri), Batı Karadeniz (Kastamonu, Sinop), Doğu Karadeniz (Gümüşhane, Bayburt), Doğu (Ağrı, Kars, Erzurum) ve Güneydoğu Anadolu'da (Malatya) görülmektedir. Akraba evliliğinin daha fazla olduğu bölgelerde hastalığın ortaya çıkma riski de artmaktadır ${ }^{6}$.

\section{Ailesel Akdeniz Ateşi Geninin Özelliği}

MEFV (Mediterranean Fever) adı verilen 3505 nükleotidlik bir diziye sahip olan bu gen Pyrin proteinini kodlamaktadır. MEFV geninin protein kodlayan 10 fonksiyonel bölgesi (10 adet ekzonu) bulunmaktadır (Tablo I). 
Tablo I. Mediterranean Fever (MEFV) Geninin Özellikleri

\begin{tabular}{|l|l|}
\hline Kromozom Bölgesi & $16 \mathrm{p} 13.3$ \\
\hline Gen Adı & MEFV (marenostrin) \\
\hline Protein uzunluğu & $781 \mathrm{aa}$ \\
\hline Ekson sayısı & 10 \\
\hline Transkript (mRNA) & $3.7 \mathrm{~Kb}$ \\
\hline Translasyon ürünü & Pyrin \\
\hline
\end{tabular}

Bugüne kadar MEFV geninde saptanan mutasyon sayısı 43 olup, çoğu 10'uncu ekzonda bulunmaktadır (Şekil2). Bunlardan 5 tanesi en sık görülen mutasyonlar olup, Ailesel Akdeniz Ateşlilerin \%85'inde görülür ve en sık görülen mutasyon ise M694V' dir ${ }^{6,7}$ (Tablo II).

Tablo II. Etnik Kökenlere Göre MEFV Genindeki Mutasyon Dağılımı

\begin{tabular}{|l|l|l|l|l|l|l|}
\hline Mutasyon Oranları (\%) & \multicolumn{1}{l|}{} \\
\hline Mutasyon & Türk (6) & Türk(11) & Türk(7) & Arap(10) & Ermeni(10) & Musevi(10) \\
\hline M694V & 51.55 & 43.5 & 51.4 & 20 & 37 & 65 \\
\hline M680I & 9.22 & 12 & 14.4 & 7 & 21 & 1 \\
\hline E148Q & 3.55 & 1.3 & 3.5 & 6 & 3 & 5 \\
\hline V726A & 2.88 & 11.1 & 8.6 & 14 & 19 & 3 \\
\hline M694I & 0.44 & 2.8 & 1.7 & 12 & 2 & 0 \\
\hline
\end{tabular}




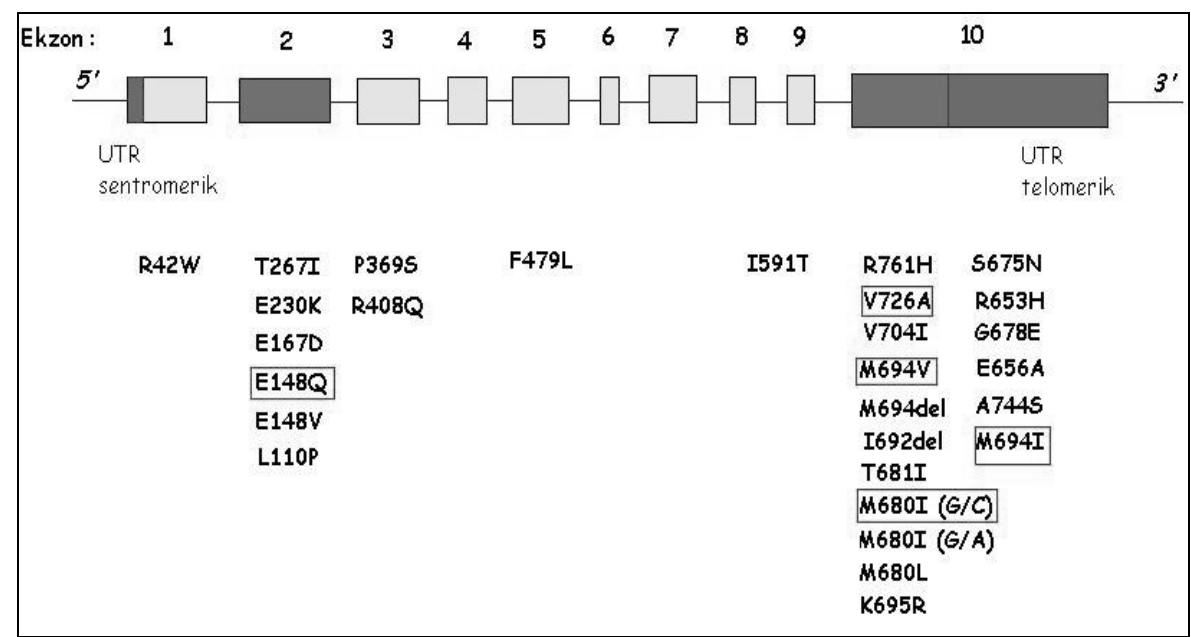

Şekil 2. MEFV mutasyon çeşitliliği. Sık görülen 5 mutasyon kare içine alınmıştır ${ }^{7}$.

\subsection{Pyrin Proteinin Özelliği}

Pyrin sınırlı doku ekspresyonu olan, özellikle nötrofillerde bulunan ve nötrofil aktivasyonu nedeniyle inflamasyonu baskılayan düzenleyici bir proteindir. Ailesel Akdeniz Ateşinde mutasyon sonucu oluşan pyrin proteini nötrofil aktivasyonundaki düzeni bozmaktadır ${ }^{6}$. Bu genin ürünü olan protein 781 aminoasit içerip, $86 \mathrm{kDa}$ büyüklüğündedir. Latince pyrexia; ateş düzenleyen protein anlamına gelir, bu proteine Amerikalılar Pyrin, Fransızlar Marenostrin, Romalılar "Mareo Nostrum: Bizim Denizimiz" adını vermişlerdir ${ }^{4}$. Arjinin ve lizin aminoasitlerinden zengin, pozitif yüklü bir proteindir. Pyrin proteini dört fonksiyonel domain içermektedir ${ }^{8,9}$ (Şekil 3). 


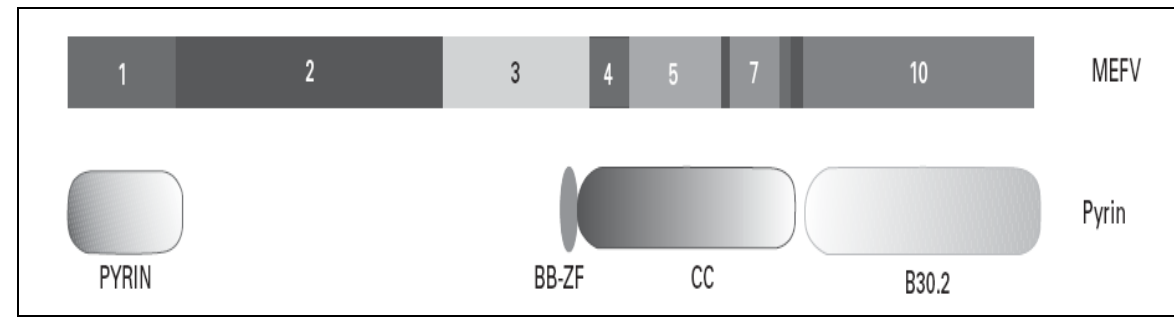

Şekil 3. MEFV geninin ekzonları ve kodladıkları pyrin proteinin domainleri

Amino (N) ucu PYRIN domaini olup ayrıca bu domain: PAD, PyD veya DAPIN olarak da isimlendirilmektedir."B box zinc finger" domain (BB-ZF), "Coiled coil" domain (CC) ve Karboksi (C) ucunda B30.2 domaini bulunur. FMF mutasyonlarının çoğu B30.2 domainini etkilemektedir. Pyrin domaini apoptosisle ilişkili proteinlere bağlanarak olayın tetiklenmesini sağlamaktadır ${ }^{10,11}$.

\section{Ailesel Akdeniz Ateşinin Belirti ve Bulguları}

\subsection{Amiloidoz}

Hastalığın istenmeyen en önemli komplikasyonu; "amiloidoz" dur. Amiloid, suda çözülmeyen bir proteindir ve Ailesel Akdeniz Ateşi sırasında yapımı artar. Ateş atakları sırasında serumda inflamasyon belirteçleri yüksek bulunur. Kanı bu proteinlerden temizlemeye çalışan böbrekler, bunu başaramaz ve biriken amiloid, böbreğin çalışmasını bozar, hastaların \%35'inde yüksek tansiyona sebep olur ve böbrek yetmezliği gelişir ${ }^{8}$. Serum amiloid $A$ protein (SAA), C-reaktif protein (CRP), kompleman ve fibrinojen artışı ile granülositoz görülür. Sıklıkla eritrosit sedimentasyon hızı da yükselmiş olarak bulunur ${ }^{11}$. Bazı eksonik veya intronik polimorfizimler, hastalığın oluşumuna, seyrine ve genetik yatkınlığına yol açabilmektedir. Bu nedenle MEFV geninin 2. exonunda yer alan 138 Gly (A-G) polimorfizmi taşıyan Ailesel Akdeniz Ateşli hastalarda amiloid gelişim riski, taşımayanlara göre 3 kat daha fazla görülmektedir ${ }^{12}$. Yapılan bazı çalışmalarda otoantikorların ekspresyonunda HLA antijeni ve bazı genetik faktörlerin de etkili olabileceği düşünülmesine 
rağmen bugüne kadar Ailesel Akdeniz Ateşinin hiçbir HLA antijeni ile ilişkisi tanımlanamamıştır ${ }^{13}$. Bazı çalışmalarda M694V mutasyonu ile amiloidoz arasındaki ilişkinin diğer amiloidoz gözlenen mutasyonlara göre daha yüksek olduğu bildirilmiştir. Otozomal resesif kalıtsalığın amiloidozu kolaylaştıran özellik olduğu düşünülmektedir ${ }^{14}$.

\subsection{Eklem Ağrısı ve Şişliği}

En tipik cilt bulgusu, genellikle diz ile ayak bileği arasında, ayak sırtında keskin kenarlı, sıcak, hassas, şiş, kırmızı plaklar ile kendini gösterir. Erkeklerde testisler, kadınlarda yumurtalıklar şişebilir. Kadınların 1/3'ü bebek sahibi olamazken, gelişen gebeliklerin de $1 / 3$ 'ü düşükle sonlanır.

\subsection{Ateş}

$39-40^{\circ} \mathrm{C}$ ve titremeyle yükselen ateş görülebilir. Kardinal belirtilerden birisidir. Ateş 12 saatten 3 güne kadar devam eder, tedavisiz kendiliğinden düşer. Ateş yüksekliğinin tek semptom olarak görülmesi nadirdir.

\subsection{Ailesel Akdeniz Ateşinde Lipid Metabolizması Bozukluğu}

Yağ metabolizmasındaki bozukluk sonucunda oluşan oksidan madde artışı membrana zarar vererek Ailesel Akdeniz Ateşi atağının artmasına ve de a Tokoferol seviyesinde azalmaya neden olur.

\section{Ailesel Akdeniz Ateşi Tanısı}

Ailesel Akdeniz Ateşi tanısında kullanılan Tel Hashomer Kriterleri şunlardır.

\section{Major kriterler:}

1. Artrit ve/veya serözitin eşlik ettiği tekrarlayan ateş atakları.

2. Predispozan bir hastalık olmaksızın gelişen AA tipi amiloidoz

3. Kolşisine iyi yanıt

\section{Minör kriterler:}

1. Tekrarlayan ateş atakları

2. Erizipel benzeri eritem 


\section{Birinci derece akrabada FMF varlığı}

Kesin tanıda 2 major veya bir majör ile 2 minör kriter, şüpheli tanıda ise bir major ve bir minör kriter bulunmaktadır ${ }^{15}$.

\section{Tedavi}

Kolşisin, atakların önlenmesinde ve amiloid oluşumunu engellemede kullanıı. Kolşisin tedavisi ile, hastalarda \%60 ataklar kesilirken \%20'sinde atakların sıklığında azalma görülür. Kolşisin hücre içindeki mikrotübül sistemini inhibe ederek monosit ve nötrofil kemotaksisini azaltır (Şekil 4).

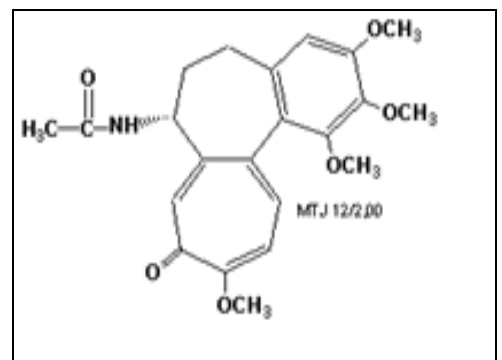

Şekil 4. Kolşisinin kimyasal yapısı

\section{Kaynaklar}

1. http://www.printo.it/pediatric-rheumatology/information/Turchia/index.htm, Erişim Tarihi (12.03.2009)

2. Erken E, Güneşaçar R, Özer H. Investigation of C5a receptor gene $450 \mathrm{C} / \mathrm{T}$ polymorphism in Turkish patients with Familial Mediterranean Fever. Mol Biol Rep 2009; 37:273-276.

3. International FMF Consortium , Ancient Missense Mutations in a new member of the roret gene family are likely to cause Familial Mediterranean Fever. Cell 1997 90: 797-807

4. Sezer İ, Kocabaş H. Ailesel Akdeniz Ateşi. Selçuk Tıp Der 2007; 24: 209-216.

5. Touitou I. The spectrum of Familial Mediterranean Fever (FMF) mutations. Eu J Human Gen 2001; 9: 473 -483.

6. Tunca M. Ailevi Akdeniz Ateşinin tarihçesi Dünya'da ve Türkiye'de Ailevi Akdeniz Ateşi. J Int Med Sci 2006; 2(8):4-8. 
7. Özlü SG. Ailevi Akdeniz Ateşi olgularında gen mutasyonları ve hastalık ağılık skorlaması ilişkisi; Kolşisin tedavisinin kan B12 vitamini düzeylerine etkisinin araştırıması. Uzmanlık Tezi. İstanbul Göztepe Hastanesi, İstanbul, 2006.

8. Yılmaz S. Ailesel Akdeniz Ateşi'nde böbrek tutulumu. İstanbul Tıp Der 2009; 72(2): 71-74.

9. Mansfield E, Chae JJ, Komarow HD. The Familial Mediterranean Fever protein, pyrin, associates with microtubules and colocalizes with actin filaments. Blood 2001; 98: 851-859.

10. Peynircioğlu B, Yılmaz E. Ailesel Akdeniz Ateşi moleküler temeli. Hacettepe Tıp Der 2006; 37: 223-229.

11. http://www.ahmetnayir.net/default.aspx?pid=56084 Erişim Tarihi (14.03.2009)

12. http://www.medicine.ankara.edu.tr/internal_medical/pediatrics/mol-gen/index.php?Pgld=76 Erişim Tarihi (16.03.2009)

13. Konca K, Erken E, Özbek $S$ ve ark. Familyal Akdeniz Ateşinde anti nötrofil sitoplazmik antikorlar. Ondokuz Mayıs Tıp Der 1995;12(4): 311-316.

14. Yalçınkaya $\mathrm{F}$, Tekin $\mathrm{M}$, Çakar $\mathrm{N}$ ve ark. Familial Mediterranean Fever and systemic amyloidosis in untreated Turkish patients. Q J Med 2000;93: 681-684.

15. Doğan DA. Çocukluk çağı Ailevi Akdeniz Ateşi hastalarında klinik ve epidemiyolojik özelliklerin belirlenmesi ve bu özelliklerle sık görülen mutasyonlar arasındaki ilişkilerin araştıııması. Bilim uzmanlığı tezi, İstanbul Üniversitesi Tıp Fak. İstanbul, 2007.

Yazışma Adresi:

Yük. Lis. Öğr. Onur ALBAYRAK

Çukurova Üniversitesi Tıp Fakültesi

Tıbbi Biyokimya Anabilim Dalı

Tel: 032233860 60/ 3466-3467

Fax: 03223386943 